\title{
Residential Location Choices of Couples Considering both Partners' Residential Biographies and Family Ties
}

\author{
Janna Albrecht, Lisa Döring, Christian Holz-Rau, Joachim Scheiner
}

\begin{abstract}
We investigate couples' residential decisions by considering variables capturing elements of both partners' residential biographies and family ties. We focus on the family formation stage because decisions made in this stage are rather long-term. We are particularly interested in the hometown as individuals have spent a great amount of time and an important life phase there. Our research questions are: (1) To what extent do people live in their hometown at family formation? (2) Which factors influence this choice? We consider previous residential experiences, social ties, socio-demographic and spatial variables in binary logit regressions. The data was collected from a sample of students at TU Dortmund University, their parents, and grandparents. In this paper, the parent couples' residential location choices are analysed considering family ties to the grandparents. We apply a rigorous split half method for internal model validation. Recent research on residential decisions mostly considers either the partners or the life-course or social ties. Due to our unique dataset, we include all these factors. This allows us to draw conclusions on gendered residential choice. We find the length of residence to be positively and number of moves negatively associated with living at the hometown, two factors that have not been disentangled in previous research. We could not confirm the often proven male dominance. On the contrary, we found that the female's family ties were more relevant. The hometown has not received the attention it deserves to date and has the potential to enrich demographic research and related fields. The rigorous split half method for internal validation has rarely been undertaken previously. The results point to the importance of model validation and thus present an innovative approach.
\end{abstract}

Keywords: Residential location · Residential biography $\cdot$ Life-course $\cdot$ Family formation · Family ties · Split half 


\section{Introduction}

The importance of the life-course for residential decisions and migration has been acknowledged in much previous research. There are various studies on residential decisions and migration focusing on certain stages of life and key events (Kley 2009; Feijten 2005), as well as interdependencies between the housing trajectory and other life-course trajectories (de Bruijn 1999; Willekens 1991). Fewer studies investigate how residential experiences made over the life-course influence later residential choices (Blaauboer 2011; Feijten et al. 2008). Moreover, there has been much more research on moves, their triggers and related destination choices than on residential inertia or return migration (except at the international level) and residential ties, although moves and particularly long-distance migration are relatively rare events. This paper investigates how residential experiences over the lifecourse influence later residential choices. In particular, we focus on the hometown, where most of childhood and adolescence is usually spent and which may have great meaning for an individual. We examine to what extent, and under which conditions, the hometown is chosen for residence at the time of family formation. This is of particular interest, as the location choice in this phase is made very consciously and is considered to be a long-term decision (Thomas et al. 2016: 587; Feijten et al. 2008: 156). What is more, the location chosen at family formation will be the hometown for the upcoming generation and may influence the future residential location choices of that generation, too.

Our research questions are: (1) To what extent do people live in their hometown at family formation? (2) Which factors influence this choice? We mainly focus on variables capturing elements of the residential biography and family ties.

By hometown we refer to the municipality level. There are some studies revealing the importance of social ties and life-course factors on international migration (Yahirun 2014; Haas/Fokkema 2011; Heering et al. 2004), while other studies look at neighbourhood choices (Clark et al. 2017). But less is known about staying at or returning to places on a local level. Returning to or staying at a place of residence allows for the use of location-specific capital built up over the life-course. To a large extent this includes social capital in terms of frequent contact with friends and family. Family ties in particular can be seen as typically being strong and lasting a whole lifetime. Moreover, people may feel emotionally attached to places where they have experienced memorable events.

This paper reveals the importance of the hometown, where most of childhood and adolescence is spent, for residential decisions at the family formation phase. The paper contributes to recent research, as it analyses household residential decisions by considering both partners, which has rarely been done before (notable exceptions are Blaauboer et al. 2011 and Løken et al. 2013). This also allows us to draw conclusions on gendered residential choice. What is more, we distinguish between variables capturing elements of (both partners') residential biographies and the influences of family ties, which are often neglected in other studies. We focus on the local level of municipalities, which has not been the spatial unit of interest 
in previous studies. Additionally, we apply a rigorous split half method for internal validation, which is rarely done in related research.

The paper is structured as follows. The next section deals with the theoretical framework and provides a literature review. We discuss the life-course approach, draw on the concepts of location-specific capital and place attachment, and focus on the influences of parental residence for their adult children's residential choices. This is followed by a description of the data and method. The results encompass descriptive findings and regression models. We also reflect on the limitations of our study. Finally, we discuss theoretical, empirical and methodological conclusions.

\section{Theoretical framework and literature review}

\subsection{Residential locations and life-course}

Following the life-course approach, an individual's biography ${ }^{1}$ can be seen as consisting of several trajectories, such as mobility, employment, residential and household (de Bruijn 1999: 156; Willekens 1991: 19-21). In life-course approaches to residential choice, two aspects receive the most attention. First, key events and life transitions in one trajectory may induce a change in the residential biography, thus a residential move. At the same time, the other parallel trajectories restrict residential choice (Mulder/Hooimeijer 1999: 163). For instance, a child's birth, a key event in the family and household biography, causes an increased need for living space and may trigger a residential move. At the same time, the new residence must be located close to the place of work, which means that the residential choice is conditioned by the employment biography. Hence, the life-course approach focuses on the interdependencies between different biography trajectories. Second, it is assumed that residential experiences over the life-course affect subsequent residential choices (Blaauboer 2011: 1646; Feijten et al. 2008: 153-156; van Dam et al. 2002: 467). Our study mainly contributes to further understanding the second aspect, which has been less studied than the first.

\subsection{Hometown}

The hometown is usually the place where an individual has spent an important life phase and a great amount of time, and from where an independent residential biography often starts. Regarding this place, we draw on the two theoretical concepts of place attachment and location-specific capital. These concepts are often discussed separately even though they are closely related (Lewicka 2011: 226).

Location-specific capital is understood as "assets that are more valuable in their current location than they would be elsewhere" (DaVanzo 1981: 46). Growing up in

1 We are aware of the conceptual difference between life-course and biography, but here we use these terms interchangeably. 
a certain place, children and adolescents build such assets. This primarily refers to friendships and family relations (social capital which has a large portion of locationspecific capital). But it also includes any kind of local knowledge, such as of the local labour market, housing market, or leisure or shopping facilities. Residential decision-making within an independent household is usually biased towards the hometown, as the greatest assets are located there. These were built in the childhood and adolescence and are tied (mostly) to the parents and depend on their past residential decisions. Leaving the place of childhood and adolescence often means forgoing the benefits of proximity to parents and other kin, and the economic and social value of hometown networks (Løken et al. 2013: 286). A move to a new place can be seen as an investment involving transaction costs, including information costs and uncertain outcomes (DaVanzo 1981, 1983). In contrast, moving back to or within the hometown may imply faster adjustment after the move, as previous activity patterns can be easily re-established. Thus, moving but staying in proximity to the hometown also means lower transaction costs.

In contrast to this socio-economic point of view, place attachment deals with affect, emotion and feeling (Low/A/tman 1992: 4). Psychological processes based on individual experiences in places during childhood, adult life or significant events in life may create place attachment (Low/Altman 1992: 4). Those individual experiences often involve social interactions with others, e.g. family members, kin, partners, friends, schoolmates, colleagues and neighbours, creating lasting memories and linking individuals to places and people. ${ }^{2}$ Place attachment interrelates with the individual's place identity (Hernandez et al. 2007: 317) and may foster self-esteem, self-worth, and self-pride (Low/Altman 1992: 10). Regarding the spatial level, Tuan (1975) describes cities as "centers of meaning" (p. 156). He expects cities to be very likely targets of attachment, as they are clearly delineated and worth labelling (Tuan 1975: 157; Lewicka 2011: 212). Several studies prove a strong place attachment to cities rather than to the intermediate neighbourhood and city district level (Hernandez et al. 2007: 317; Hidalgo/Hernandez 2001: 279; Lewicka 2010: 42). Both location-specific capital (especially social capital) and place attachment are mostly built through social interactions. Having resided at a place often (but not necessarily) leads to high location-specific capital and strong place attachment, as evidenced by Bonaiuto et al. (1999: 344-345) and Brown et al. (2003: 268). Thus, from an economic and emotional point of view, living in the hometown seems to be beneficial despite possible limitations in the labour market. Nonetheless, there is no unidirectional causality, which means that place attachment and location-specific capital may also lead to a longer length of residence and fewer moves.

\subsection{Union formation and residential locations of couples}

Union formation (cohabiting or marital) is a significant event in both partners' residential biographies. Unions are often formed around the same time as other life

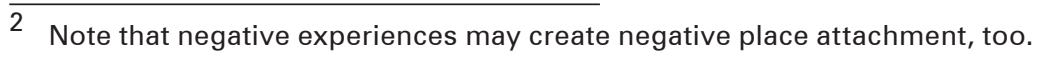


events, e.g. graduating from school, first or new employment, or a child's birth. While it is argued that cohabitation is chosen in uncertain or unstable life situations with an unclear immediate future, marrying seems to be more strongly associated with stability and certainty (Guzzo 2006: 402; Duvander 1999: 712-713). From this point on, residential decisions are made jointly, depending on the bargaining power of both partners. This power depends on socio-economic status, associated with level of education, employment and age, as well as gender role beliefs (Cooke 2008: 172; Smits et al. 2003: 611-612). Research has confirmed the male partner's dominant bargaining position in residential decisions (Bie/by/Bielby 1992: 1256-1259). Especially dual-earner households face the challenge of residential decisions involving a trade-off between both partners' employment and income opportunities (Smits et al. 2003: 611-612; Abraham et al. 2010: 889). Even though we do not mainly focus on the gendered perspective of residential decisions, we briefly introduce bargaining theory here as it helps understand and interpret the decisions jointly made by both partners.

\subsection{The birth of a child and residential location at family formation}

The birth of a child, especially of the first child, is a significant event in an individual's and couple's family and household biography and is strongly associated with residential decisions (Michielin/Mulder 2008: 2787-2788). With the anticipation of a child's birth, housing requirements often change and residential aspirations become more important. Even though residential decisions are always constrained by economic circumstances, the housing and labour market and other life-course trajectories, the residential decision at family formation is considered to be more self-determined, conscious and rather long-term (Thomas et al. 2016: 585; Feijten et al. 2008: 156). It is associated with an increased demand for housing space (Lersch 2014: 141) and home ownership (Beer/Faulkner 2009: 47-48). Requirements regarding the neighbourhood environment may change and lead to a residential decision towards a suburban environment (Gerber 2011: 273-274). Social ties, especially to the partner's parents, become more important, as they commonly provide caregiving (Blaauboer et al. 2011: 608; Michielin/Mulder 2007: 673). Especially dual-earner families face the challenge of childcare and employment.

\subsection{Adults' Parents' residential location}

The influence of parental residential locations on an adult individual's residential location has been studied widely, mostly by focusing on the geographical distance between parents and their adult children. In most studies the units of analysis are individuals (Chudnovskaya/Kolk 2017; Kolk 2017; van den Broek et al. 2014; Isengard 2013; Mulder/van der Meer 2009; Michielin et al. 2008; Michielin/Mulder 2007; Mulder/Cooke 2009; Rogerson et al. 2007). Only very few studies have examined the residential distance between couples (as the unit of analysis) and both partners' parents (Blaauboer 2011; Løken et al. 2013). Some studies focus on the distance between elderly parents and their adult children as a function of the elderly parents' 
care needs (Lundholm 2015; Van der Pers et al. 2014; Van der Pers/Mulder 2013; Bordone 2009; Malmberg/Pettersson 2007; Hank 2007). Less attention has been paid to the role of young parents' need for childcare, with the exception of $L \varnothing k e n$ et al. (2013). Close proximity is a precondition for face-to-face contact and for the provision of support such as childcare. In line with the hypothesis of male dominance in residential choice, it has been shown that heterosexual (married) couples live closer to the man's parents than to the woman's (Løken et al. 2013: 292; Blaauboer et al. 2011: 603). Having children increases the proximity to parents (Lawton et al. 1994: 63; Løken et al. 2013: 302). Generally, this refers to both sets of parents (Blaauboer et al. 2011: 604). However, having young children decreases the distance to the female's parents, but not to the male's parents (Blaauboer et al. 2011: 604-607). This may mean that couples rely more on the support of the woman's parents when it comes to childcare.

Higher education is associated with greater intergenerational distance (Kolk 2017: 9, 12; Lawton et al. 1994: 63). For couples, higher education of either partner increases the distance to both sets of parents. Men's education is found to be more relevant than women's and more relevant for the distance to men's parents (Blaauboer et al. 2011: 604-606; Løken et al. 2013: 302). A higher age of the couple is also associated with longer distances. The distance increase is larger to the male's parents than to the female's parents. This indicates that after an initial dominance of the socio-economic position of the male partner, the female's family ties get more important and females seem to gain more bargaining power in residential decisionmaking (Blaauboer et al. 2011: 607). Kolk (2017: 6) shows that after the child leaves the parental home, distance increases between the parents and the child gradually, flattening out when the child reaches the age of 27. Couples living in an urbanised area have been found to be more distant to both parents (Blaauboer et al. 2011: 606). Couples move farther from their parents living in rural locations than from parents living in urban locations ${ }^{3}$ (Løken et al. 2013: 302). While Lawton et al. (1994: 63) found that homeowners are more likely to live within a one-hour distance from their parents than non-homeowners, Blaauboer et al. (2011: 607) did not find homeownership to have a significant effect on the distance to parents.

Considered overall, we expect the following from the literature. Residential location choices should be influenced by both partners' residential biography and life events, marital status, employment, age, education (and income), the bargaining positions of both partners, social and especially family networks. Externally, this is constrained by the labour and housing markets (pricing and political conditions).

$\overline{3}$ This holds for women and highly educated men. 


\section{$3 \quad$ Data}

\subsection{Survey design and data collection}

The data used in this study was collected through a paper-based questionnaire. The survey focus is on daily travel and holiday trips, but rich information on residential, employment and family biographies was included as well. The information was retrospectively collected from a sample of first-year students in spatial planning at TU Dortmund University, their parents and grandparents. The data encompasses unique information on both the life-course and family members outside the household, which is not provided by other panel surveys such as SOEP and pairfam. ${ }^{4}$

First-year students were asked to fill out the questionnaire for themselves and, if possible, to interview their parents and one maternal and one paternal grandparent. ${ }^{5}$ From 2007 onwards, the survey has been carried out every year (Scheiner et al. 2014). The data used is in trend form, with retrospectively collected information on the life-course. This paper considers the data gathered from 2007 to 2012. In the first five years, participation in the survey was compulsory, with a response rate of over 90 percent. In 2012, students participated voluntarily (due to a change in the examination regulations), and the response rate thus dropped to around 20 percent (Döring et al. 2014). See footnote 6 for more information.

\subsection{Information collected on residential biographies}

The information on the residential biography can be divided into two parts. The first part contains the data relevant until setting up a household of one's own. It includes information on the place where childhood and adolescence were mainly spent, more precisely the municipality name (free text response), its size (number of inhabitants classified in seven categories, self-rated by the respondent) and country. It is important to highlight that the respondents had to define this place subjectively. Thus it is unclear what age the respondent was when they lived there, how long they lived there and which other characteristics the place had. In the interest of simplification, the main location of childhood and adolescence is hereafter referred

4 SOEP (German Socio-Economic Panel) does not provide information on family members outside the household. Pairfam (Panel Analysis of Intimate Relationships and Family Dynamics) does not encompass such rich information on the residential biography of the couples' parents.

5 The students were asked to choose the grandparent to be interviewed by applying the lastbirthday method. We nevertheless expect the interviewed family members to be biased towards married and younger parents and grandparents, who live closer to the student and to whom the student feels more emotionally tied. Hence, there should be selection bias in the data we use towards those members of a generation whom the student feels more emotionally tied to. These ties are, however, not directly relevant, as our analysis considers the ties between parents and grandparents. What is more, the events our study refers to happened decades prior to the data collection. Nontheless, there may be bias to the extent the students' ties depend on ties between parents and grandparents, and affect the sample selection. This may lead to slightly overestimated family tie effects. 
to as the hometown. Moreover, the place of birth, the number of moves in childhood and adolescence and the main person(s) with whom a respondent grew up are recorded.

The second part starts from the last residential location before setting up a household of one's own and ends at the time of data collection. For a maximum of 12 residences, the year of relocation, the municipality name and municipality size are gathered, along with other attributes not relevant here.

\subsection{Sample}

The dataset contains information on 960 families. Each family consists of up to five persons from up to three generations. The youngest generation in the dataset is represented by students (954 individuals). The middle generation encompasses 926 females and 861 males. The oldest generation is made up of 812 females and 482 males $^{6}$ (Döring et al. 2014).

In this paper, the analysis is limited to the family formation phase. The units of analysis are couples of the middle generation, as most of the students have not yet reached the family formation stage. Hereafter they are referred to as the couple (cohabitating or married), female/male partners or just females and males. The family ties included in the analysis refer to ties between the middle generation and the oldest generation, hereafter referred to as the couples' parents (i.e. students' grandparents). On average, the investigation period is the late 1980s, when the middle generation started a family.

The females are born in 1959 on average (std. dev. 4.8), the males in 1956 (std. dev. 5.8). The couples' parents' average year of birth is 1931 (std. dev. 7.0), with mothers and the females' parents being slightly younger. A descriptive analysis of sociodemographics shows differences from the national averages in age distribution, level of education and nationality. These deviations could be attributed to the survey design, which defines the sample based on the students. However, despite these differences, general social developments in German society such as the expansion of education, barriers in the educational system and increasing female participation in the labour force can also be observed in the dataset (Döring et al. 2014). Due to the survey design, the respondents' residential locations are biased towards the Ruhr Area (and North Rhine-Westphalia) compared to the German population. The Ruhr Area is characterised by high population density, accessibility, a high density of educational facilities, large job and housing markets which may increase the likelihood of staying in the place of origin compared to more remote regions. For this region, our dataset shows characteristic residential biographies. ${ }^{7}$ Even though

688 percent of all participating students interviewed both parents, 8 percent interviewed only their mother, 2 percent only their father and 2 percent did not interview any parent. 58 percent of the students interviewed two grandparents, 20 percent interviewed one grandparent, and 23 percent did not interview any grandparent.

7 Encompassing flight and displacement from today's Poland during WWII and labour migration in the subsequent decades. 
it is not representative of the German population as a whole, it covers a large population in a highly populated region.

\section{$4 \quad$ Method}

\subsection{Logistic regression and split half method}

We use logistic regression models to estimate the following two dependent variables:

a) Couple lives in female's hometown at family formation (yes $=1 / \mathrm{no}=0$ )

b) Couple lives in male's hometown at family formation (yes $=1 / \mathrm{no}=0$ )

For model validation, we rigidly apply the split half method. For this purpose, the sample is randomly divided into two halves based on the families at the beginning of the project ( $n=480$ families for each sample). The final model presented is developed with one half of the sample (training sample, trained model) as a result of an iterative process. The second half of the sample is used to test the previously developed model (validation sample, validation model).

In the social sciences, this approach is not widely used. It is more common practice to develop a model step by step, adjusting it to the data used. As the model building process is often not accurately documented, it remains unclear whether the model presented was strictly derived from the theory or was chosen out of a great number of model variations. Models may vary by the way the included variables were processed in advance, the type and set of independent variables or other model specifications. Researchers may tend to choose the model which confirms their hypotheses or/and allow model building to be strongly driven by data. Such procedures are statistically incorrect (if not validated with an independent sample), and may lead to a significance bias in published results (Arlot/Celisse 2010; Steyerberg et al. 2001; Snee 1977: 420). We present the trained models (see Models A in Table 3 and Table 4) and validation models (see Models B in Table 3 and Table 4) for each of the abovementioned dependent variables.

\subsection{Variables}

As noted above, the unit of analysis is the couple and thus information on both partners is required. Moreover, both partners' parents' residential locations are included, so only cases with one female's parent and one male's parent are considered in the analyses. This reduces the number of cases from 960 to 317 (169 in the training sample and 148 in the validation sample). The strong reduction is mainly due to deceased or otherwise inaccessible grandparents and (to a lesser extent) parents.

\section{Identifying joint children}

Most of the couples in the dataset have joint children (at least the student who interviewed them). Some of them formed their union later in life, e.g. in a second mar- 
riage after having children with other partners. Each respondent individually stated their number of children and year of birth. We used this information combined with the years of marriages and divorces to identify whether the couple has joint children and when they were born. This ensured that both partners were linked in a particular point in time and that the event of a child's birth appeared in both partners' lives at the same time.

\section{Defining the family formation phase}

Defining a point in time as the family formation phase is not as easy as it seems. We carried out descriptive analyses on the number of moves and length of residence in relation to the first joint child's birth. Relocations are most commonly made in the year of the first joint child's birth or shortly before, rather than after, the first joint child's birth. The number of moves decreases rapidly after the first child's birth. Similar results are found by Michielin/Mulder (2008) and Kulu (2008). Households with small children (up to the age of 7 years) on average remain in the place of residence more than 10 years after a relocation, which is rather long compared to moves made without children and with older children. Similar results have been found by Feijten et al. (2008: 153-155). Combining these results, we define the family formation phase as a point in time two years after the first joint child's birth. We assume that by this time most households have relocated as they have adapted to a child's birth and stay at the location they have moved to for a long period. Furthermore, a two-year-old infant needs intensive childcare, which can be provided by family members outside the household.

\section{Identifying joint households and residential location}

A couple with a two-year-old joint child does not necessarily live in a joint household. Unfortunately, there is no information on household size and composition in the residential biographies collected. We assume that two non-divorced partners stating the same municipality lived in the same joint household. ${ }^{8}$ In case a residential relocation was carried out in the year of family formation, the location to which the household moved is defined as the location at family formation.

Out of 317 cases, 290 couples are identified as having at least one joint child and living in the same household two years after their first joint child was born (158 in the training sample and 132 in the validation sample).

\section{Coding the residential locations}

The respondents stated a great number of different locations that required coding. This was undertaken within the Federal Republic of Germany at the municipality level using the territorial status of 31 March 2011 and the 12-digit official municipality key (Regionalschlüssel) from the Federal Statistical Office. Places abroad were

8 This can be further supported by correlations between two partners' attributes of residential location (location within the municipality and location within the municipality district). 
coded as far as possible on the NUTS-3-level. The dependent variables were created based on the coded places.

\section{Variables on residential biography}

Residential biography influences can have multiple facets. We basically consider the length of residence in the hometown and the number of moves made in the past. We calculated the respondent's length of residence in their own hometown (Table 1; L4, L7 and L10, L13). In addition, we consider the respondent's length of residence in their partner's hometown (L5, L6; L8 L11, L12, L14) as we assume both partners' place attachment and location-specific capital are taken into account in the couple's residential location choice. We are aware that length of residence does not directly measure place attachment and location-specific capital. We rather use these two theoretical concepts to interpret and understand the found effects. As stated in Section 2.2, we expect direct links between place attachment and locationspecific capital on the one hand, and length of residence on the other.

The length of residence ${ }^{9}$ in the hometown over the whole life-course until family formation $(L 4, L 5, L 10, L 11)$ is comprised of the length of residence until setting up a household of one's own $(L 6, L 12)$ and the length of residence from setting up a household of one's own until family formation (L7, L8, L13, L14), ${ }^{10}$ as residential decisions are made differently in these two time periods (dependent on parental decisions vs. independently with a household of one's own). The respondent's length of residence in their hometown until setting up an independent household is not included in the analyses, and thus not listed in Table 1 as these variables show low variances. The corresponding partner's variables (L6 and L12) are strongly associated with the couple growing up in the same hometown. As described above, less information has been collected on the respondents' residential biographies before they set up an independent household. However, due to the survey design some of this information can be reconstructed using the complementary information of the parents as they shared a household with their child during this time period. The procedure and the quality of the reconstructed data are addressed in Albrecht et al. (2017). ${ }^{11}$

9 We calculated the absolute length of residence in years. We also tested the relative length of residence by calculating the share of the years spent in the hometown of all years possible (i.e. the age at family formation, the age at setting up a household of one's own and the years from setting up a household of one's own until family formation.

${ }^{10} \mathrm{~L} 4=$ female's length of residence in female's hometown (not in Table 1) + L7

$\mathrm{L} 5=\mathrm{L} 6+\mathrm{L} 8$

$\mathrm{L} 10=$ male's length of residence in male's hometown (not in Table 1) $+\mathrm{L} 13$

$\mathrm{L} 11=\mathrm{L} 12+\mathrm{L} 14$

11 The minimum number of years spent in the own hometown ( $L 4$ and L10) is zero, which may be surprising. This is due to the complementary data used for the reconstruction and applies only to very few cases. 
The number of moves $(L 15, L 16)$ is generally associated with a higher probability of having moved to another place and the gained ability of dealing with new circumstances after a move.

\section{Family tie variable}

All respondents were asked to state with whom they predominantly grew up. We assume family ties between the respondents and their parents even in cases where respondents did not state that they predominantly grew up with the parent who participated in the questionnaire. This refers to a very small number of cases (4 out of 290 both for the females and males).

The parents mostly (still) live in the respondent's hometown (86 percent of the female's parents and 88 percent of the male's parents). In some cases, parents-inlaw live in a respondent's hometown. The vast majority of these cases also have their own parents living in the same place. Hence, we created one variable considering both partners' parents (L17, L18). It should be noted that the variable "female's and male's parents live in female's hometown" (L17) is related to the male's length of residence in the female's hometown until setting up a household of his own (L6). Conversely, the variable "female's and male's parents live in male's hometown" (L18) is related to the female's length of residence in the male's hometown until setting up a household of her own (L12).

\section{Socio-demographic variables}

The age and level of education strongly correlate between both partners. Hence, we merge both partners' information into one variable for a couple's average age and maximum level of education (L19 and L20). We expect age to have a negative effect on living in someone's hometown, as it implies having more time for moving to another place. It may also be linked to a more advanced occupational career and thus more moves made for job reasons.

Respondents with high levels of education are more likely to relocate for job reasons due to the highly specialised labour market, and thus they are less likely to live in their own or their partners' hometown. ${ }^{12}$

\section{Spatial variable}

Due to the small number of cases, the original seven categories of the hometown population size are summarised into three according to municipality population types by $B B S R$ (2015). We assume growing up in a major municipality leads to a higher probability of living there at a later life phase, as short-distance moves do not involve leaving the municipality due to its larger area. Please note that municipality size is associated with greater labour market access and a tighter housing market.

\footnotetext{
$\overline{12}$ Note that level of education is measured at the time of the survey and not at family formation.
} 


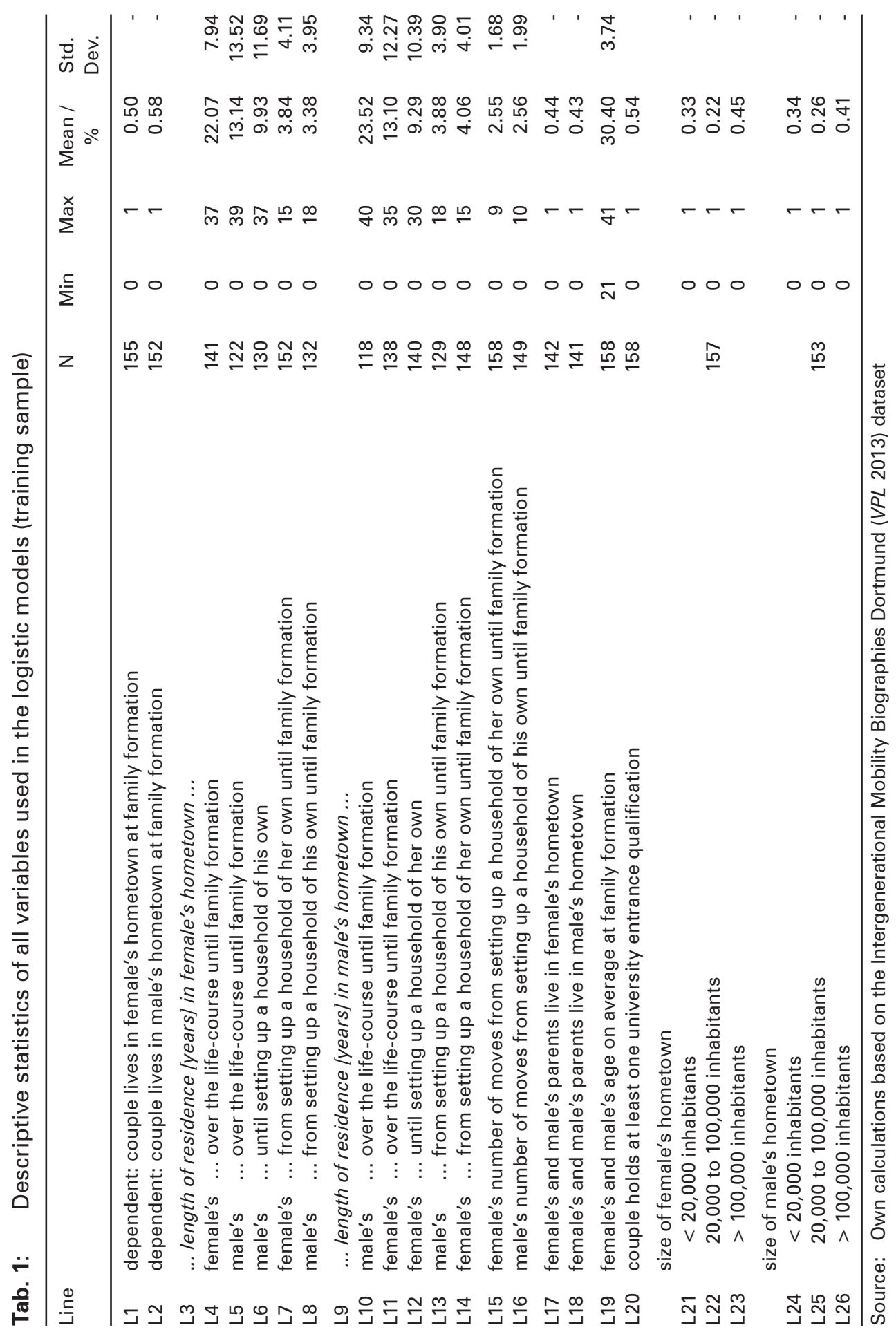




\section{$5 \quad$ Results}

\subsection{Descriptive Results}

Before answering the research questions, we introduce some findings which help us interpret and contextualise the follow-up results.

The following descriptive results cover the entire sample (training and validation sample). Females set up an independent household at the age of 21 (std. dev. 3) and males at 23 (std. dev. 4). Compared to the German population in the same cohort, this is slightly younger (Hullen 1998). As mentioned above, the time of investigation is around 1989 (std. dev. 3, range 1972 to 1995), when the couple formed a family (two years after the first joint child's birth). At this time, the couple is around 30 years old (std. dev. 4, range 21 to 41 ), females are on average 2 years younger than their partners. 2 percent of the females and 7 percent of the males stated that they did not set up an independent household until family formation, i.e. they were probably living in the parental home. The others moved twice on average before they resided at the location where they formed a family. About a quarter stated that they formed a family at the first location they moved to with an independent household. At the time of investigation, on average the female's parents are 58 years old whereas the male's parents are 60 .

Table 2 shows the results for answers to the first research question. 181 out of 270 couples (67 percent) live in the hometown of at least one partner. 137 of all couples live in the female's hometown and 146 live in the male's hometown. 51 percent $(\mathrm{N}=138)$ of the couples face a potential location conflict as they have different hometowns (see Table 2). A similar number of married couples with their parents in different municipalities is stated in Løken et al. (2013). 43 percent of these do not live in the hometown of either of the partners. For those living in the hometown of one of the partners, the male's hometown is more likely to be chosen (32 percent compared to 25 percent). Again, this result resembles other studies (Løken et al. 2013: 295; Blaauboer et al. 2011). Couples with the same hometown are less likely to live in neither of the partner's hometowns ( 23 compared to 43 percent).

Seven percent of the females $(N=21)$ and 10 percent of the males $(N=27)$ state Dortmund as their hometown. 66 percent (females $\mathrm{N}=186$ and males $\mathrm{N}=182$ ) call another municipality in North Rhine-Westphalia their home. 18 percent of the females $(N=52)$ and 16 percent of the males $(N=45)$ grew up elsewhere in (mostly former West) Germany and 8 percent (females and males) abroad. The shares of the couples who live in either the female's or male's hometown are the highest for Dortmund, followed by elsewhere in North Rhine Westphalia. The shares for other municipalities in Germany and places abroad are comparably low. This result is due to the sampling of students in Dortmund. 
Tab. 2: $\quad$ Couples with different/same hometowns and living in the female's/ male's hometown (training and validation sample)

\begin{tabular}{|c|c|c|c|c|c|}
\hline & & & $\begin{array}{r}\text { couple liv } \\
\text { at }\end{array}$ & $\begin{array}{l}\text { in male's } \\
\text { mily forma }\end{array}$ & $\begin{array}{l}\text { fometown } \\
\text { ion }\end{array}$ \\
\hline & & & no & yes & Total \\
\hline couple has different hometowns & & & & & \\
\hline couple lives in female's hometown & no & Count / \% & $59 / 43$ & $44 / 32$ & $103 / 75$ \\
\hline at family formation & Total & Count / \% & $35 / 25$ & $44 / 32$ & $\begin{array}{r}35 / 25 \\
38 / 100\end{array}$ \\
\hline couple has the same hometown & & & & & \\
\hline couple lives in female's hometown & no & Count / \% & $30 / 23$ & $-/-$ & $30 / 23$ \\
\hline at family formation & yes & Count / \% & $-1-$ & $102 / 77$ & $102 / 77$ \\
\hline Total & & & & $102 / 78$ & \\
\hline couple lives in female's hometown & no & Count / \% & 89 / 33 & 44 / 16 & $133 / 49$ \\
\hline at family formation & & & $35 / 13$ & $102 / 38$ & $137 / 51^{*}$ \\
\hline & Total & Count / \% & $124 / 46$ & $146 / 54^{*}$ & 270 / 100 \\
\hline
\end{tabular}

* Please note that the percentages do not match with Table 1, as this table shows the numbers for the entire sample (traning and validation sample) and Table 1 only for the training sample.

Source: Own calculations based on the Intergenerational Mobility Biographies Dortmund (VPL 2013) dataset

\subsection{Models}

To answer the second research question, we show the results of logistic regression models. Building and choosing the final models was challenging for several reasons. The sample size shrank enormously from 480 (each sample) to 158 (training sample) and 132 (validation sample). When testing multiple independent variables, the sample size fell below 100 cases. Moreover, the independent variables highly correlate with each other. This applies to various variables of the same respondent (e.g. age at family formation and level of education) and to the same variables measured for respondents and their partners (e.g. level of education or length of residence). In this case, including numerous independent variables led to low model stability. Consequently, high priority is given to model parsimony and stability. Hence, in the following, we show several parsimonious models (rather than one comprehensive model). ${ }^{13}$

All models in Table 3 and Table 4 were developed with the training sample (Models A) and tested afterwards with the validation sample (Models B). ${ }^{14}$ For the validation model, the results of the significance tests are presented without showing Exp(B), as all models (except Model 7 in Table 3) indicate the effect in the same direction as the training models. All significance tests were carried out one-tailed as

\footnotetext{
13 Please note that we use pooled data from six waves of a trend survey. We do not include the year of data collection as a control variable as there was no significant effect of the year of survey on our outcome. What is more, the Kruskal-Wallis test does not show statistically significant differences between the years in any variable.

14 Models with the whole sample size will be provided by the authors on request.
} 


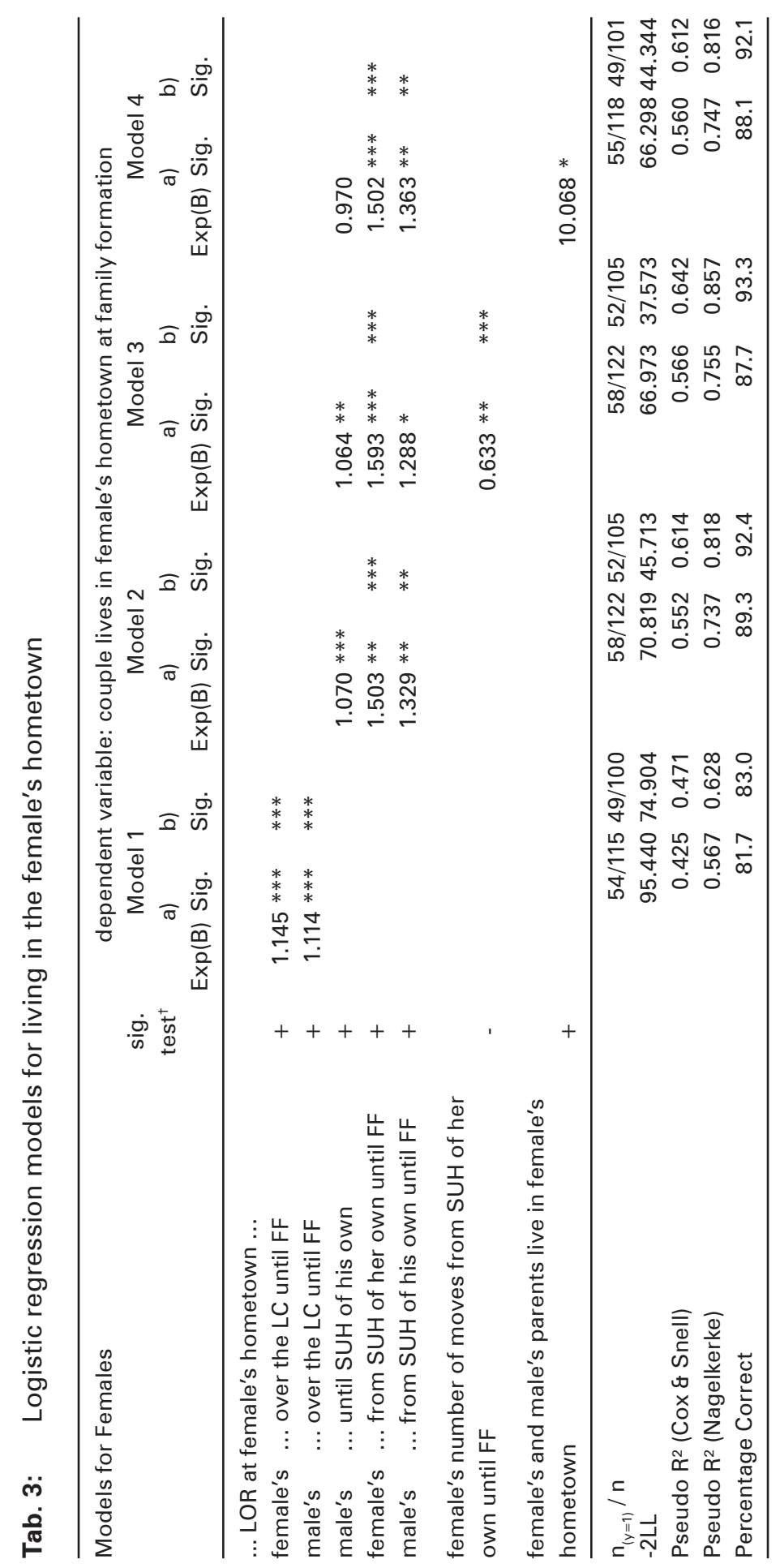




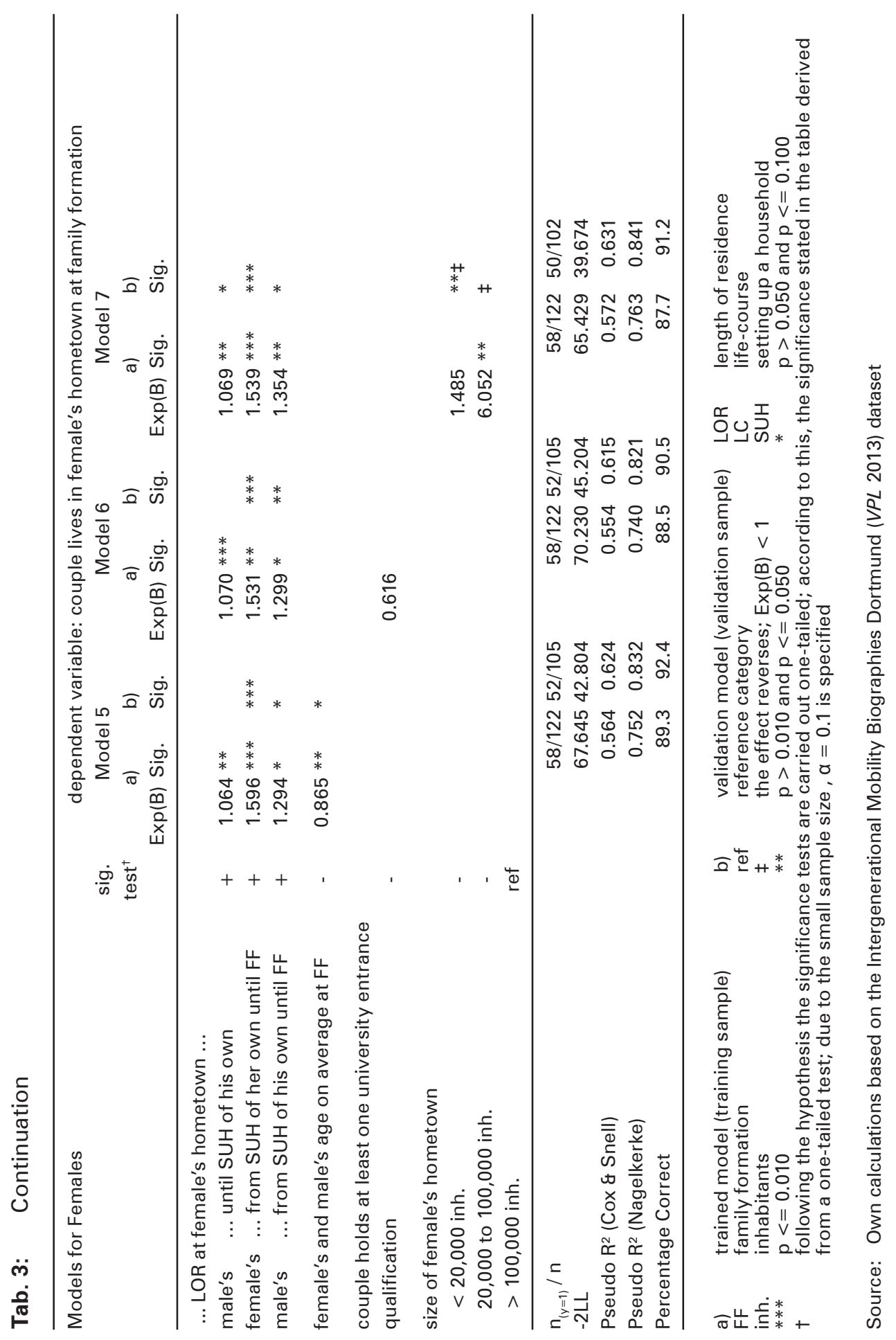


124 - Janna Albrecht, Lisa Döring, Christian Holz-Rau, Joachim Scheiner

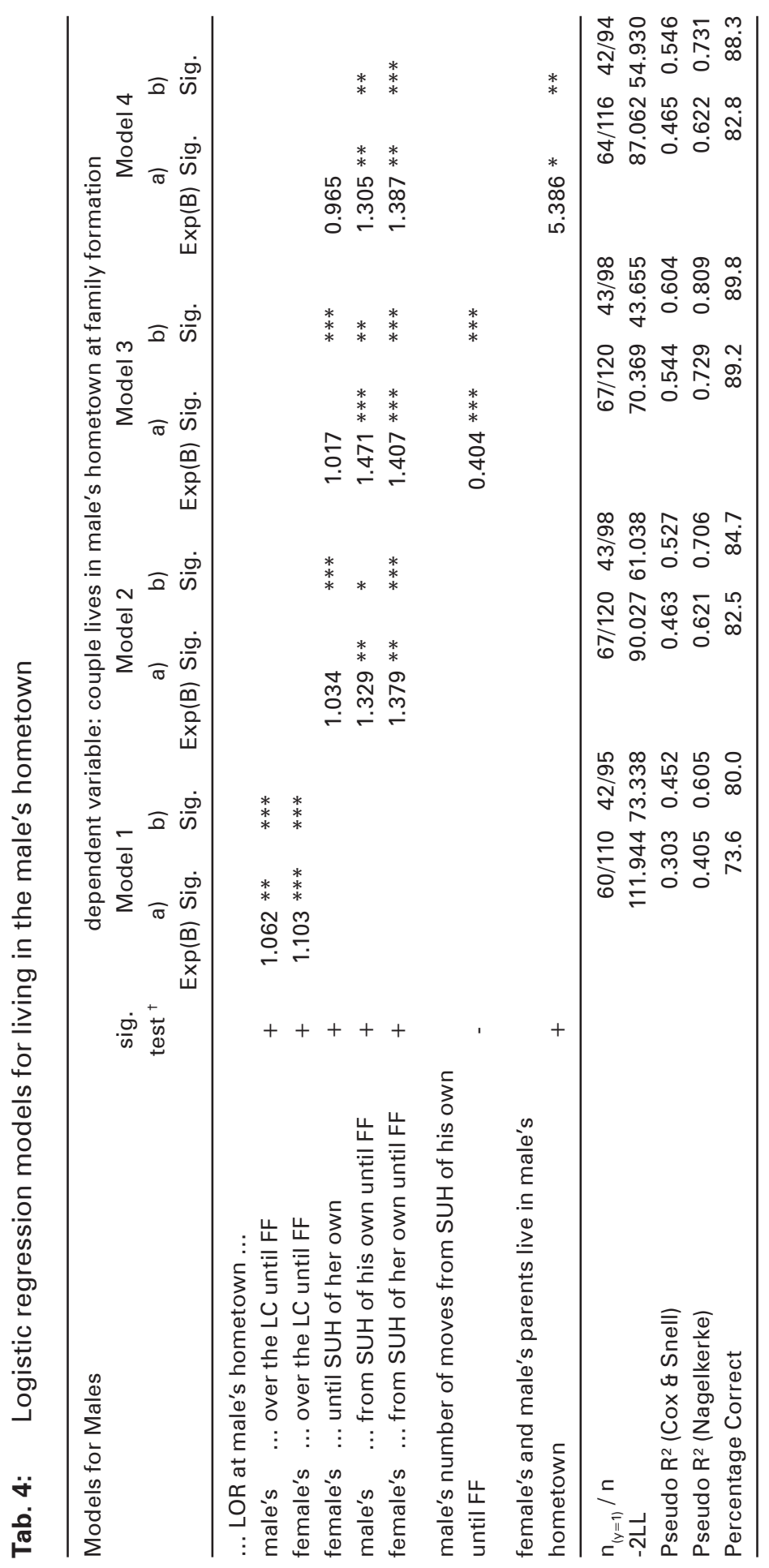




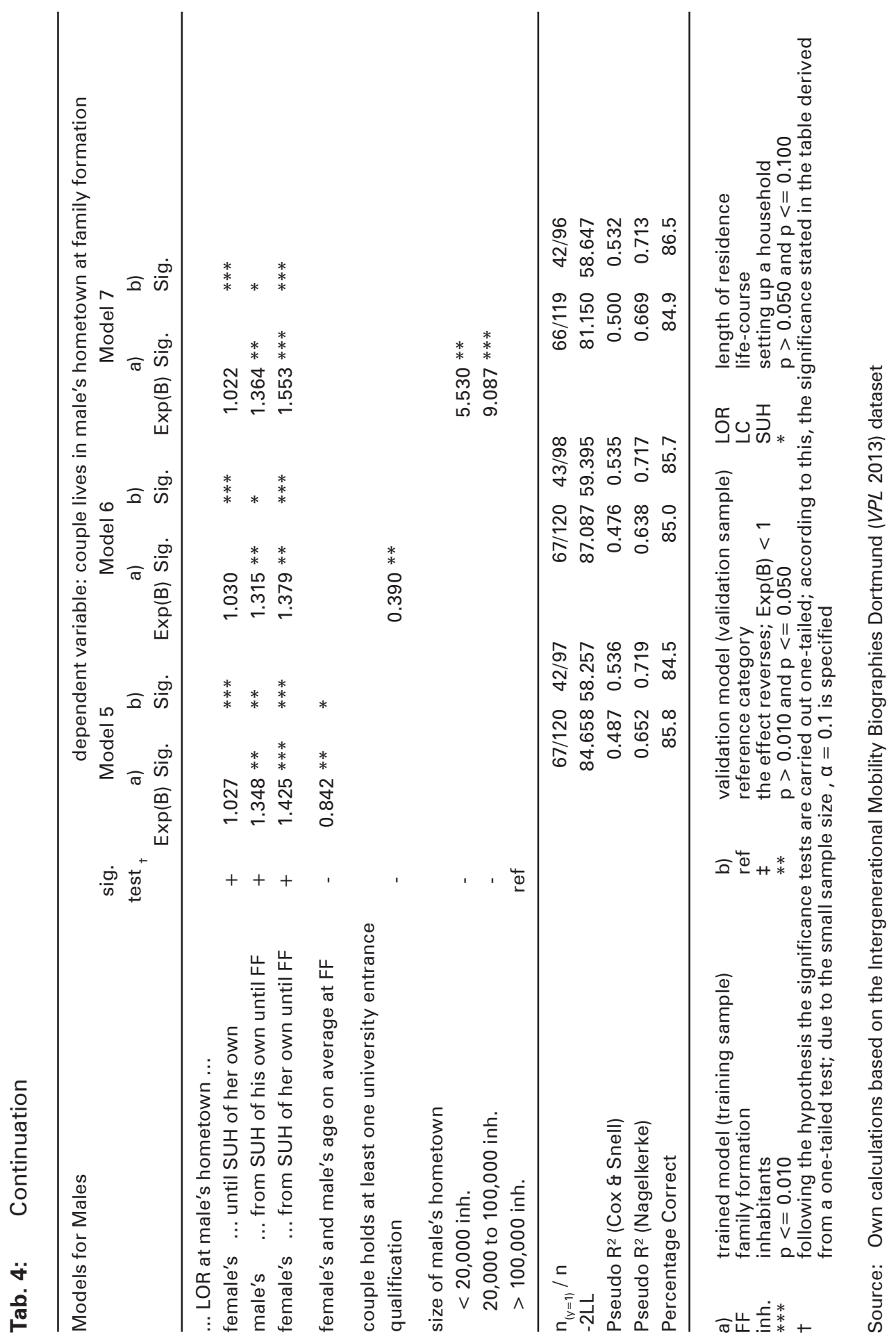


all hypotheses (derived from the literature and theoretical framework) were formulated in a one-sided manner (see Table 3 and Table 4, column sig. test). Considering the small sample size, we reject the $\mathrm{H}_{0}$ hypotheses up to $p<0.1$.

Please note that results on gendered aspects are obtained by comparing the models for females and models for males and the males' and females' variables included in the models.

\section{Residential biography}

We started building the models with both partners' lengths of residence in their hometown until family formation (see Table 3 and Table 4, Models 1) as we expect residential biographies to be very inert. The effects are in the expected direction $(+)$ and roughly equal in size. The longer both partners lived in the female's/male's hometown, the more likely the couple was to live in the female's/male's hometown at family formation. Even though only two independent variables are included in the models, the pseudo- $\mathrm{R}^{2}$ are quite high. This indicates strong bonds to the hometown over the life-course. The model fit of the model for females (Model 1 in Table 3) is higher than of the model for males (Model 1 in Table 4).

Next, we replaced the total length of residence in the hometown with the length of residence at this place until and from setting up a household of one's own (Models 2 in Table 3 and Table 4). In the models for females, the female's and male's length of residence from setting up a household are significant (Model 2a and $2 \mathrm{~b}$ in Table 3). In the model for males, only the female's length of residence from setting up a household shows a significant effect in the training and validation models (Model 2a and 2b in Table 4). It is important to note that the details on one partner's length of residence in the other's hometown are unclear. Due to the questionnaire design, it is not clear from the reported moves whether the partner moved to this place with an independent household (for example for work or educational reasons) and met their partner later, or the partner moved there in order to form a union with the other. But we can draw some conclusions from the stated reasons for relocation. These indicate that females are slightly more likely to move for partnership reasons. ${ }^{15}$ Yet the male's place attachment and location-specific capital may depend on the length of residence at that place, as the male's variable almost achieves significance in the validation model (Model $2 b$ in Table 4), and shows significance in all follow-up models. From the training models, it appears that for a couple living in the male's hometown, the female's length of residence at that place until setting up

1520 percent of both males and females state a child's birth as the reason to move. Other commonly reported reasons are partnership (marriage or cohabitation), homeownership and increased demand for housing space, which seem appropriate for the family formation phase. Females state partnership reasons more often ( 25 percent compared to male's 19 percent), whereas males report homeownership reasons more often (17 percent compared to female's 13 percent). Furthermore, the results indicate that males not living in their hometown are less likely to report partnership reasons than the same females. This may hint that females are more likely to be tied movers. It must be noted that a couple's move may be reported with different reasons by the female and the male partner. Social desirability bias may be relevant in this context as well. 
an independent household is insignificant (model 2a in Table 4), while the male's is significant for living in the female's hometown (model 2a in Table 3). This would support the idea of a male-dominant bargaining position in the household's residential decision-making process. But this interpretation is not supported by the validation models (models $2 \mathrm{~b}$ in Table 3 and in Table 4), which show divergent significance compared to the trained models. This points to the importance of the split-half approach.

The model fits of Models 2 are 0.1 higher than those of Models 1. This indicates that the differentiation between lengths of residence in different life phases is reasonable. We take this as a basic model (Model 2) to introduce one variable at a time (Models 3 to 7).

The number of moves from setting up an independent household is found to have a significant effect for both males and females (Models 3a in Table 3 and in Table 4) and is confirmed in the validation models (Models $3 \mathrm{~b}$ Table 3 and in Table 4). ${ }^{16}$ The effect is as expected. The more moves the female has made, the less likely it is that the couple lives in her hometown (Model 3 in Table 3). The same applies to the models of males using the male's number of moves (Model 3 in Table 4). ${ }^{17}$ Although the number of moves and the length of residence in the hometown from setting up a household of one's own weakly correlate with each other, ${ }^{18}$ length of residence remains significant in Models 3 (compared to Models 2). This suggests two distinct effects from the length of residence and the number of moves. Moves seem to weaken the tie to the hometown. Experiencing and coping with moves may increase confidence in being able to deal with future moves, leading to new residential locations outside the hometown.

\section{Family ties}

In order to consider family ties, the variable on whether the female's and male's parents live in the female's/male's hometown was included. It is significant in both trained models (Models $4 \mathrm{a}$ in Table 3 and in Table 4) but is only confirmed in the model for males (Model $4 \mathrm{~b}$ in Table 4). The female's family ties seem to have an influence on couples living in the male's hometown, whereas no significant effect of the male's family ties is shown for living in the female's hometown. This suggests that the female's family ties are more important at the family formation stage, perhaps because the female's parents are more likely to be trusted with childcare. Adding these variables to the models leads to insignificant (and reverse) effects of the length of residence until setting up a household of one's own. As mentioned before, this is due to a high correlation of these two variables. Basically, the questionnaire used allows us to distinguish between the hometown (where the childhood

16 The number of moves was tested as a categorical variable to investigate how many moves matter. Due to the small number of cases which are unevenly distributed in categories and unclear results, the number of moves was not implemented as a categorical variable.

17 The partner's number of moves is not tested as there are no expected effects.

18 This is only significant for the male's variables. 
and adolescence was predominantly spent) and the parents' residential location, but in most cases the data collected show the same place for both. Although the question of how people make residential choices when their parents have left their hometown may be of interest, it cannot be answered here due to the small number of such cases in the dataset.

\section{Age}

In line with the hypotheses, the couple's average age at family formation ${ }^{19}$ has a negative significant effect in all four models (Models $5 \mathrm{a}$ and $5 \mathrm{~b}$ in Table 3 and in Table 4). The older the couple is at family formation, the less likely it is that they live in the female's or male's hometown. This result fits the effects shown for the number of moves (Models 3). It may be related to the more advanced occupational career of older couples who have previously moved away from their hometown for job reasons. It may also point to a smaller need for family support as an older couple might be more (financially) independent.

\section{Education}

It could be assumed that age reflects another effect. People with a high level of education tend to be older at the birth of their child(ren) and are more likely to have left their hometown for educational or employment reasons. This interpretation, however, is not likely, as we tested the level of education at the couple level. Holding at least one university entrance qualification ${ }^{20}$ indicates an influence in the expected direction, but reaches significance only in the trained model for males (Model 6a in Table 4). This is somewhat surprising, as we would expect highly skilled labour to need to move in order to meet labour market requirements.

\section{Hometown population size}

An interesting result is observed for the hometown population size. The trained models (Models 7a in Table 3 and in Table 4) indicate that growing up in mediumsized municipalities $(20,000$ to 100,000 inhabitants) leads to a higher probability of living there at family formation (compared to growing up in bigger municipalities). This is surprising and does not confirm the hypothesis. This is even more surprising as Dortmund has a population size of about 600,000 and thus falls into the category of the biggest population size. We would expect the results to be biased towards growing up in Dortmund, leading to a higher probability of couples living there. In the females' model, the effects reverse and thus support the hypothesis - even

19 We tried to include both partners' ages, the age difference between partners and young age (here: the youngest 25 and 10 percent of couples), but none of these variables showed significant and stable effects.

20 We attempted to include various variables such as level of education (categorical) for each partner, each partner's university degree and one partner being more highly qualified in the analyses. The variable "couple holds at least one university entrance qualification" appeared to be the most stable. 
though they are not significant. ${ }^{21}$ In the males' model, the effects point in the same (positive) direction as those in the initial model (also not significant). Overall, we fail to reject the $\mathrm{H}_{0}$ hypotheses. One possible explanation is the influence of housing prices at the time or a strong wish for homeownership which could not be fulfilled through residence in a large municipality such as Dortmund. It could also indicate suburbanisation and families preferring smaller and less industrial municipalities due to the more child-friendly environment, especially at the time of family foundation for the data in question, which was around $1990 .^{22}$

All follow-up models (Models 3 to 7 ) show slightly higher pseudo- $\mathrm{R}^{2}$ (higher increase in the models for males). All models for females show higher model fit than models for males (except for percentage correctly predicted in Model 2a). Thus, females' residential decisions are more predictable than males'.

The model accuracies of the validation models are all greater than those of the corresponding trained models. The $-2 \mathrm{LL}$ decreases in all models compared to the basic model indicate that the additionally added variable in every model has additional explanatory power.

The significances of the length of residence variables vary slightly between the models, but stay roughly at the same level as in the basic model. These seem to be stable effects in all model variations.

Comparing the female's and male's lengths of residence from setting up a household of one's own among all models (Models $\mathrm{F}$ and $\mathrm{M}$ ), the female's variable shows a stronger effect. On the one hand, this could speak against the male dominance hypotheses. On the other hand, it has to be noted that it is unclear which partner moved to form a union.

\subsection{Bias and Missing Information}

Several factors could not be considered in our analysis due to the questionnaire design or small numbers of cases. As mentioned above, we could not provide deeper insight into the event of union formation. It is uncertain which of the partners moved (both, only female, only male), where they lived when they started a relationship, and how long they have been a couple. We did not collect data on marital status, as we found that the vast majority of the couples were married and the variable thus did not show enough variance. We did not consider the couple's employment. It was not clear for the respondents whether maternity leave should be stated in the questionnaire. This mostly applies to the females and makes it impossible to identify dual-earner households for the time of family formation. We did not analyse the chronology, timing and sequences of other life events, which would be of great

$\overline{21}$ We assume that the deviating results in both samples are caused by significantly different variances of one covariate and multicollinearity.

22 Due to the characteristics of the Ruhr Area (see Section 3.3.) we would expect a positive effect of the Ruhr Area on living in one of the partner's hometowns. Unfortunately, the survey design does provide a distinction between different regions. 
interest, but could not be considered due to the questionnaire design and number of cases. We also did not have any information on income. As described above, the residential locations are biased towards the Ruhr Area, a highly populated, polycentric metropolitan region. As such, it has a large labour and housing market, a wide range of educational facilities and high transport accessibility.

\section{Conclusions}

This paper studied residential location choices with respect to two questions.

1.) To what extent do people live in their hometown at family formation? We found that one-third of all couples live in neither of the partners' hometowns. More than half of the others live in both partners' hometown. If the couple lives in only one partner's hometown, it is more likely to be the male's hometown.

2.) Which factors influence the choice of the hometown at family formation? The results show the high relevance of the life-course perspective. People maintain a strong bond to their hometown over the life-course. They are very inert, even over generations. The results provide evidence that the length of residence and number of moves have distinct and significant effects, which have not been untangled in previous research. This suggests that place attachment and location-specific capital increase with length of residence and decrease with the number of moves, although we do not have direct evidence on emotional and economic ties. We conclude that more attention should be paid to life-course influences (e.g. places of origin or childhood roots) in demographic research. This may be relevant for other disciplines as well, such as the social sciences or even transport research. Transport research places much emphasis on the residential environment (e.g., urban/suburban/rural), but neglects ties to particular places whose relevance emerges from the life-course and from social networks, although the social networks have gained importance in the field in recent years (Kim et al. 2018). We believe that this perspective could enrich discussions in this field.

What is more, age at family formation is negatively associated with living in the hometown. This may indicate more advanced occupational careers, higher levels of independence and less need for family support.

The influence of the level of education and municipality size cannot be identified. We assume that this is due to the study region, the Ruhr Area. In a polycentric metropolitan region with very high accessibility, it may be possible to stay in the hometown and still make use of higher education facilities and a large labour market within commuting distance.

From a gendered perspective, on the one hand, living in the female's hometown seems to be more pre-determined and less likely. On the other hand, the female's experience with places of residence has a stronger influence on a couple's residential choice. We do not find clear evidence of the often-discussed male dominance on residential location choice despite the finding that couples more frequently choose the male partner's place of childhood than the female partner's. Regarding this, we need to keep in mind that the respondents in our dataset are highly educated 
and mostly from an urban region and may therefore have less traditional lifestyles. Another contributing reason may be the investigated life stage. Previous research found the residential location in this life stage was more strongly dominated by females. We confirm that the female's parents' residential location is more important than the male's, proving women's strong family ties at family formation.

It is of further research interest how place attachment, location-specific capital and social ties interact and influence residential location choices. These concepts have been neither theoretically brought together and conceptualised nor empirically disentangled and analysed in depth. Further light needs to be shed on union formation, as it often precedes family formation. Other life-course trajectories and key events need to be considered too, such as employment and commuting needs, health, and social networks. The influence of the chronology, timing and sequences of other life events on residential decisions would be of great interest. Analysis could be extended to other life phases (educational phases, children leaving home, retirement) and spatial levels (neighbourhood, region). The housing and labour market could be included as external factors influencing residential decisions as well.

The split-half approach proved to be useful and meaningful to the results. Some of the effects found in the training sample are not confirmed by the validation sample. This shows how data-driven and misleading the models and hence the interpretation would have been without internal validation. The split-half approach and other model validation procedures (such as cross-validation, bootstrapping, jackknife etc.) are not standard practice in the social sciences. Based on our experience with this method, we strongly endorse the application of statistical validation processes (Döring 2018). More detail in the documentation of model development would also be helpful for the critical appraisal of results. Even though we strongly recommend validation, we experienced its limitations: Both samples are small in size. This, among other challenges, led to parsimonious models rendering it impossible to include all tested variables in one comprehensive model. Small sample sizes make it necessary to trade off between model validation and higher levels of model complexity.

\section{Acknowledgements}

This paper presents some results of the project "Mobility Biographies: A LifeCourse Approach to Travel Behaviour and Residential Choice", which involves cooperation between three universities in Germany and Switzerland (TU Dortmund University, Goethe University Frankfurt and ETH Zurich). This project was supported by the German Research Foundation (DFG - Deutsche Forschungsgemeinschaft, funding numbers SCHE 1692/1-1/2 and HO 3262/5-1/2). The corresponding author's stay at the University of Connecticut was supported by a research scholarship from the German Academic Exchange Service (DAAD - Deutscher Akademischer Austauschdienst). 


\section{References}

Abraham, Martin; Auspurg, Katrin; Hinz, Thomas 2010: Migration Decisions Within Dual-Earner Partnerships: A Test of Bargaining Theory. In: Journal of Marriage and Family 72,4: 876-892 [doi: 10.1111/j.1741-3737.2010.00736.x].

Albrecht, Janna; Holz-Rau, Christian; Scheiner, Joachim 2017: Life-course data reconstruction using complementary information taken from linked lives. In: Transportation Research Part A: Policy and Practice 104: 308-318 [doi: 10.1016/j.tra.2017.03.016].

Arlot, Sylvain; Celisse, Alain 2010: A survey of cross-validation procedures for model selection. In: Statistics Surveys 4: 40-79 [doi: 10.1214/09-SS054].

BBSR 2015: Laufene Stadtbeobachtung - Raumabgrenzungen. Stadt- und Gemeindetypen in Deutschland [URL: http://www.bbsr.bund.de/BBSR/DE/Raumbeobachtung/ Raumabgrenzungen/StadtGemeindetyp/StadtGemeindetyp_node.html, 31.08.2017].

Beer, Andrew; Faulkner, Debbie 2009: 21st century housing careers and Australia's housing future. AHURI Final Report No. 128. Melbourne.

Bielby, William T.; Bielby, Denise D. 1992: I Will Follow Him: Family Ties, Gender-Role Beliefs, and Reluctance to Relocate for a Better Job. In: American Journal of Sociology 97,5: 1241-1267 [doi: 10.1086/229901].

Blaauboer, Marjolein 2011: The Impact of Childhood Experiences and Family Members Outside the Household on Residential Environment Choices. In: Urban Studies 48,8: 1635-1650.

Blaauboer, Marjolein; Mulder, Clara H.; Zorlu, Aslan 2011: Distances between Couples and the Man's and Woman's Parents. In: Population, Space and Place 17: 597-610 [doi: 10.1002/psp.648].

Bonaiuto, Marino et al. 1999: Multidimensional Perception of Residential Environment Quality and Neighbourhood Attachment in the Urban Environment. In: Journal of Environmental Psychology 19,4: 331-352 [doi: 10.1006/jevp.1999.0138].

Bordone, Valeria 2009: Contact and proximity of older people to their adult children: a comparison between Italy and Sweden. In: Population, Space and Place 15,4: 359-380 [doi: 10.1002/psp.559].

Brown, Barbara; Perkins, Douglas D.; Brown, Graham 2003: Place attachment in a revitalizing neighborhood: Individual and block levels of analysis. In: Journal of Environmental Psychology 23,3: 259-271 [doi: 10.1016/S0272-4944(02)00117-2].

Chudnovskaya, Margarita; Kolk, Martin 2017: Educational Expansion and Intergenerational Proximity in Sweden. In: Population, Space and Place 23,1: e1973 [doi: 10.1002/ psp.1973].

Clark, William A.V.; Duque-Calvache, Ricardo; Palomares-Linares, Isabel 2017: Place Attachment and the Decision to Stay in the Neighbourhood. In: Population, Space and Place 23,2: 1-16 [doi: 10.1002/psp.2001].

Cooke, Thomas J. 2008: Gender role beliefs and family migration. In: Population, Space and Place 14,3: 163-175 [doi: 10.1002/psp.485].

DaVanzo, Julie 1981: Repeat Migration, Information Costs and Location-Specific Capital. In: Population and Environment 4,1: 45-73 [doi: 10.1007/BF01362575].

DaVanzo, Julie 1983: Repeat Migration in the United States: Who Moves Back and Who Moves On? In: The Review of Economics and Statistics 65,4: 552-559 [doi: $10.2307 / 1935923]$. 
de Bruijn, Bart 1999: Foundations of Demographic Theory. Choice, Process, Context. PDOD publication series A (doctoral dissertations). Amsterdam: Thela Thesis.

Döring, Lisa 2018: Mobilitätsbiografien und Mobilitätssozialisation. Eine quantitative Analyse von Sozialisations-, Alters-, Perioden- und Kohorteneffekten in Alltagsmobilität. Wiesbaden: Springer Fachmedien Wiesbaden [doi: 10.1007/978-3-658-22825-5].

Döring, Lisa; Albrecht, Jana; Holz-Rau, Christian 2014: Generationsübergreifende Mobilitätsbiografien - Soziodemografische Analyse der Erhebung [http://www.URLwillbeplacedafterreview.de, 25.04.14].

Duvander, Ann-Zofie E. 1999: The Transition From Cohabitation to Marriage: A Longitudinal Study of the Propensity to Marry in Sweden in the Early 1990s. In: Journal of Family Issues 20,5: 698-717 [doi: 10.1177/019251399020005007].

Feijten, Peteke 2005: Life events and the housing career. A retrospective analysis of timed effects. Delft: Eburon.

Feijten, Peteke; Hooimeijer, Pieter; Mulder, Clara H. 2008: Residential Experience and Residential Environment Choice over the Life-course. In: Urban Studies 45,1: 141-162 [doi: 10.1177/0042098007085105].

Gerber, Kim 2011: Räumliche Mobilität im Wandel. Wanderungen im Lebenslauf und ihre Auswirkungen auf die Stadtentwicklung in Nordrhein-Westfalen. 1st ed. Wiesbaden: VS Verlag für Sozialwissenschaften [doi: 10.1007/978-3-531-92909-5].

Guzzo, Karen Benjamin 2006: The relationship between life course events and union formation. In: Social Science Research 35,2: 384-408 [doi: 10.1016/j.ssresearch.2005.06.002].

Haas, Hein de; Fokkema, Tineke 2011: The effects of integration and transnational ties on international return migration intentions. In: Demographic Research 25,24: 755-782 [doi: 10.4054/DemRes.2011.25.24].

Hank, Karsten 2007: Proximity and Contacts Between Older Parents and Their Children: A European Comparison. In: Journal of Marriage and Family 69,1: 157-173 [doi: 10.1111/j.1741-3737.2006.00351.x].

Heering, Liesbeth; van der Erf, Rob; van Wissen, Leo 2004: The Role of Family Networks and Migration Culture in the Continuation of Moroccan Emigration: A Gender Perspective. In: Journal of Ethnic and Migration Studies 30,2: 323-337 [doi: 10.1080/1369183042000200722].

Hernández, Bernardo et al. 2007: Place attachment and place identity in natives and non-natives. In: Journal of Environmental Psychology 27,4: 310-319 [doi: 10.1016/j. jenvp.2007.06.003].

Hidalgo, M. Carmen; Hernández, Bernardo 2001: Place Attachment: Conceptual and Empirical Questions. In: Journal of Environmental Psychology 21,3: 273-281 [doi: 10.1006/jevp.2001.0221]

Hullen, Gert 1998: Lebensverläufe in West- und Ostdeutschland. Längsschnittanalysen des deutschen Family and Fertility Surveys. Schriftenreihe des Bundesinstituts für Bevölkerungsforschung 26. 1st ed. Wiesbaden: VS Verlag für Sozialwissenschaften.

Isengard, Bettina 2013: "Der Apfel lebt nicht weit vom stamm": Wohnentfernungen zwischen Eltern und ihren erwachsenen Kindern in Europa. In: Comparative Population Studies 38,2: 263-290 [doi: 10.4232/10.CPoS-2013-09de].

Kim, Jinhee; Rasouli, Soora; Timmermans, Harry J. P. 2018: Social networks, social influence and activity-travel behaviour: a review of models and empirical evidence. In: Transport Reviews 38,4: 499-523 [doi: 10.1080/01441647.2017.1351500]. 
Kley, Stefanie 2009: Migration im Lebensverlauf. Der Einfluss von Lebensbedingungen und Lebenslaufereignissen auf den Wohnortwechsel. 1st ed. Wiesbaden: VS Verlag für Sozialwissenschaften.

Kolk, Martin 2017: A Life-Course Analysis of Geographical Distance to Siblings, Parents, and Grandparents in Sweden. In: Population, Space and Place 23,3: e2020 [doi: 10.1002/psp.2020].

Kulu, Hill 2008: Fertility and Spatial Mobility in the Life Course: Evidence from Austria. In: Environment and Planning A 40,3: 632-652 [doi: 10.1068/a3914].

Lawton, Leora; Silverstein, Merril; Bengtson, Vern L. 1994: Affection, Social Contact, and Geographic Distance Between Adult Children and Their Parents. In: Journal of Marriage and Family 56,1: 57-68 [doi: 10.2307/352701].

Lersch, Philipp M. 2014: Geburten und die Wohnraumversorgung von Familien: Anpassungen der Wohnung im zeitlichen Verlauf. Childbirth and Room Stress among Families: Housing Adjustments over Time. In: Zeitschrift für Soziologie 43,2: 131-149 [doi: 10.1515/zfsoz-2014-0205].

Lewicka, Maria 2010: What makes neighborhood different from home and city? Effects of place scale on place attachment. In: Journal of Environmental Psychology 30,1: 3551 [doi: 10.1016/j.jenvp.2009.05.004].

Lewicka, Maria 2011: Place attachment. How far have we come in the last 40 years? In: Journal of Environmental Psychology 31,3: 207-230 [doi: 10.1016/j.jenvp.2010.10.001].

Løken, Katrine V.; Lommerud, Kjell Erik; Lundberg, Shelly 2013: Your Place or Mine? On the Residence Choice of Young Couples in Norway. In: Demography 50,1: 285-310 [doi: 10.1007/s13524-012-0142-8].

Low, Setha M.; Altman, Irwin 1992: Place Attachment. A Conceptual Inquiry. In: Altman, Irwin; Low, Setha M. (Eds.): Place Attachment. Human Behavior and Environment 12. New York: Springer US: 1-12.

Lundholm, Emma 2015: Migration and Regional Differences in Access to Local Family Networks Among 60-year olds in Sweden. In: Population Ageing 8,3: 173-185 [doi: 10.1007/s12062-015-9117-z].

Malmberg, Gunnar; Pettersson, Anna 2007: Distance to old parents. Analyses of Swedish register data. In: Demographic Research 17,23: 679-704 [doi: 10.4054/ DemRes.2007.17.23].

Michielin, Francesca; Mulder, Clara 2007: Geographical distances between adult children and their parents in the Netherlands. In: Demographic Research 17,22: 655-678 [doi: 10.4054/DemRes.2007.17.22].

Michielin, Francesca; Mulder, Clara H. 2008: Family events and the residential mobility of couples. In: Environment and Planning A 40: 2770-2790 [doi: 10.1068/a39374].

Michielin, Francesca; Mulder, Clara H.; Zorlu, Aslan 2008: Distance to Parents and Geographical Mobility. In: Population, Space and Place 14: 327-345 [doi: 10.1002/psp.509].

Mulder, Clara H.; Cooke, Thomas J. 2009: Family ties and residential locations. In: Population, Space and Place 15,4: 299-304 [doi: 10.1002/psp.556].

Mulder, Clara H.; Hooimeijer, Pieter 1999: Residential Relocations in the Life Course. In: van Wissen, Leo J. G.; Dykstra, Pearl A. (Eds.): Population Issues. An Interdisciplinary Focus. New York: Kluwer Academic/Plenum Publishers: 159-186.

Mulder, Clara H.; van der Meer, Marieke J. 2009: Geographical Distances and Support from Family Members. In: Population, Space and Place 15,4: 381-399 [doi: 10.1002/ psp.557]. 
Rogerson, Peter A.; Burr, Jeffrey A.; Lin, Ge 2007: Changes in Geographic Proximity between Parents and their Adult Children. In: International Journal of Population Geography 3,2: 121-136 [doi: 10.1002/(SICI)1099-1220(199706)3:2<121::AIDIJPG60>3.0.CO;2-I].

Scheiner, Joachim; Sicks, Kathrin; Holz-Rau, Christian 2014: Generationsübergreifende Mobilitätsbiografien - Dokumentation der Datengrundlage [http://www.URLwillbeplacedafterreview.de, 25.4.14].

Smits, Jeroen; Mulder, Clara H.; Hooimeijer, Pieter 2003: Changing Gender Roles, Shifting Power Balance and Long-distance Migration of Couples. In: Urban Studies 40,3: 603-613 [doi: 10.1080/0042098032000053941].

Snee, Ronald D. 1977: Validation of Regression Models: Methods and Examples. In: Technometrics 19,4: 415-428 [doi: 10.1080/00401706.1977.10489581].

Steyerberg, Ewout W. et al. 2001: Internal validation of predictive models: Efficiency of some procedures for logistic regression analysis. In: Journal of Clinical Epidemiology 54,8: 774-781 [doi: 10.1016/S0895-4356(01)00341-9].

Thomas, Michael; Stillwell, John; Gould, Myles 2016: Modelling Mover/Stayer Characteristics across the Life Course Using a Large Commercial Sample. In: Population, Space and Place 22,6: 584-598 [doi: 10.1002/psp.1943].

Tuan, Yi-Fu 1975: Place: An Experiential Perspective. In: The Geographical Review 65,2: 151-165 [doi: 10.2307/213970].

van Dam, Frank; Heins, Saskia; Elbersen, Berien S. 2002: Lay discourses of the rural and stated and revealed preferences for rural living. Some evidence of the existence of a rural idyll in the Netherlands. In: Journal of Rural Studies 18,4: 461-476 [doi: 10.1016/ S0743-0167(02)00035-9].

van den Broek, Thijs; Dykstra, Pearl A.; Schenk, Niels 2014: Regional Economic Performance and Distance Between Parents and Their Employed Children - a Multilevel Analysis. In: Population, Space and Place 20,3: 222-234 [doi: 10.1002/psp.1757].

van der Pers, Marieke; Kibele, Eva U. B.; Mulder, Clara H. 2014: Intergenerational proximity and the residential relocation of older people to care institutions and elsewhere. In: Ageing and Society 35,7: 1429-1456 [doi: 10.1017/S0144686X14000300].

van der Pers, Marieke; Mulder, Clara H. 2013: The Regional Dimension of Intergenerational Proximity in the Netherlands. In: Population, Space and Place 19,5: 505-521 [doi: 10.1002/psp.1729].

VPL, Department of Transport Planning, TU Dortmund University 2013: Intergenerational Mobility Biographies Dortmund. Data from a quantitive survey among students, their parents and grandparents (2007 to 2012). Dortmund.

Willekens, Frans J. 1991: Understanding the Interdependence Between Parallel Careers. In: Siegers, Jacques J.; Jong-Gierveld, Jenny; Imhoff, Evert (Eds.): Female Labour Market Behaviour and Fertility. A Rational-Choice Approach. Population Economics. Berlin/Heidelberg: Springer Berlin Heidelberg: 11-31 [doi: 10.1007/978-3-642-765506_2].

Yahirun, Jenjira J. 2014: Take Me "Home": Return Migration among Germany's Older Immigrants. In: International Migration 52,4: 231-254 [doi: 10.1111/imig.12009]. 
Janna Albrecht ( $₫)$. ILS - Research Institute for Regional and Urban Development, Research Group Mobilities and Space. Dortmund, Germany.

E-mail: janna.albrecht@ils-forschung.de

URL: https://www.ils-forschung.de/en/the-ils/ils-staff/albrecht-janna/

Lisa Döring, Prof. Dr. Christian Holz-Rau, Prof. Dr. Joachim Scheiner. TU Dortmund University, Faculty of Spatial Planning, Department of Transport Planning. Dortmund, Germany. E-mail: lisa.doering@tu-dortmund.de, christian.holz-rau@tu-dortmund.de, joachim.scheiner@tu-dortmund.de

URL: http://www.vpl.tu-dortmund.de/cms/en/Folder_with_PhD_studies/lisa/index.html http://www.vpl.tu-dortmund.de/cms/en/Staff/Department_Head/holz-rau.html http://www.vpl.tu-dortmund.de/cms/en/Staff/Scientific_Staff/scheiner.html 


\section{Comparative Population Studies}

WWW.comparativepopulationstudies.de

ISSN: 1869-8980 (Print) - 1869-8999 (Internet)

\section{Published by}

Prof. Dr. Norbert F. Schneider

Federal Institute for Population Research D-65180 Wiesbaden / Germany

\section{(c) BY-SA}

2019

\section{Managing Editor \\ Prof. Philip Rees \\ Dr. Katrin Schiefer}

\section{Copy Editor}

Julia Luther

\section{Editorial Assistant}

Beatriz Feiler-Fuchs

Wiebke Hamann

\section{Layout \\ Beatriz Feiler-Fuchs \\ E-mail:cpos@bib.bund.de}

\section{Scientific Advisory Board}

Karsten Hank (Cologne)

Michaela Kreyenfeld (Berlin)

Marc Luy (Vienna)

Natalie Nitsche (Vienna)

Peter Preisendörfer (Mainz)

Zsolt Spéder (Budapest)

Rainer Wehrhahn (Kiel)

\section{Board of Reviewers}

Martin Abraham (Erlangen)

Laura Bernardi (Lausanne)

Hansjörg Bucher (Bonn)

Claudia Diehl (Konstanz)

Andreas Diekmann (Zurich)

Gabriele Doblhammer-Reiter (Rostock)

Jürgen Dorbritz (Wiesbaden)

Anette Eva Fasang (Berlin)

E.-Jürgen Flöthmann (Bielefeld)

Alexia Fürnkranz-Prskawetz (Vienna)

Beat Fux (Salzburg)

Joshua Goldstein (Berkeley)

Sonja Haug (Regensburg)

Hill Kulu (Liverpool)

Aart C. Liefbroer (The Hague)

Kurt Lüscher (Konstanz)

Emma Lundholm (Umeå)

Nadja Milewski (Rostock)

Dimiter Philipov (Vienna)

Roland Rau (Rostock)

Tomáš Sobotka (Vienna)

Jeroen Spijker (Barcelona)

Olivier Thévenon (Paris)

Helga de Valk (Brussels)

Heike Trappe (Rostock)

Michael Wagner (Cologne) 